\title{
Soft tissue mass at the infrascapular fossa
}

\author{
Seng-Choe Tham • Andrew E. Horvai - Thomas Link • \\ Lynne Steinbach
}

Published online: 15 April 2010

(C) The Author(s) 2010. This article is published with open access at Springerlink.com

\section{Question}

A 23-year-old man with a 5-year history of acute lymphoblastic leukemia (ALL) and who was in remission after chemotherapy treatment presenting with a shoulder mass (Figs. 1-4).

Open Access This article is distributed under the terms of the Creative Commons Attribution Noncommercial License which permits any noncommercial use, distribution, and reproduction in any medium, provided the original author(s) and source are credited.

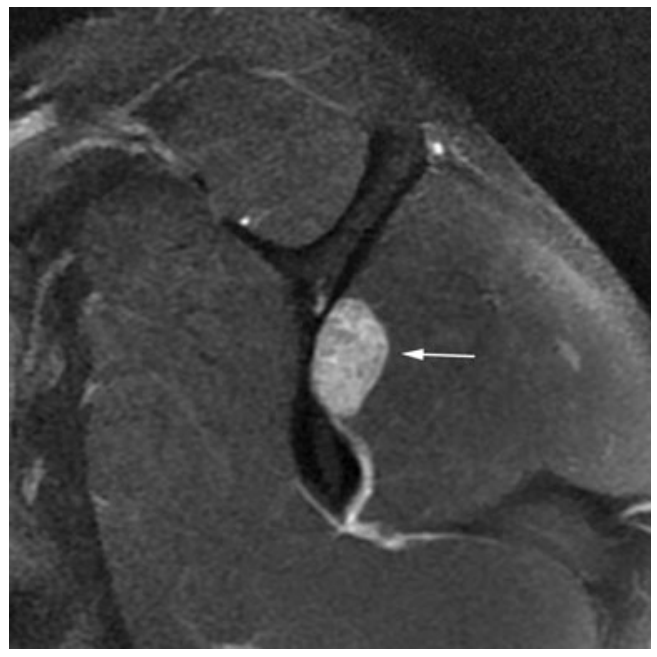

Fig. 1 Sagittal oblique T1-weighted fast spin echo image with chemical fat saturation and intravenous gadolinium reveals heterogeneous enhancement of a mass within the infrascapular region (arrow)

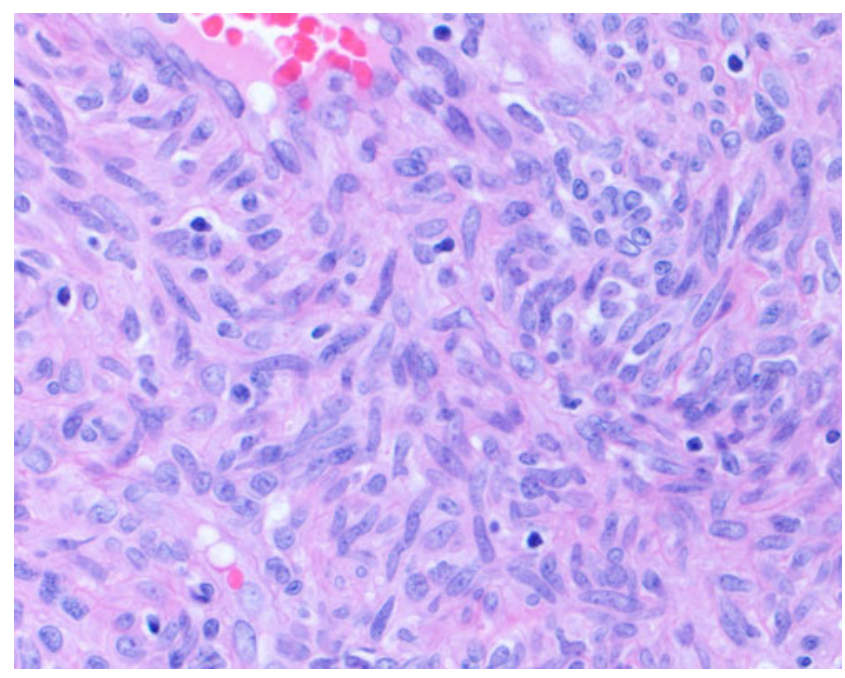

Fig. 2 The tumor was composed of short, intersecting fascicles of spindle cells with scattered small lymphocytes (original magnification, $\times 400$ )
The diagnosis can be found at doi:10.1007/s00256-010-0916-2.

This case was presented as Case 35 at the Members Meeting of the International Skeletal Society in Washington DC, 2009

S.-C. Tham $\cdot$ T. Link $\cdot$ L. Steinbach

Department of Radiology, University of California,

San Francisco, USA

\section{A. E. Horvai}

Department of Pathology, University of California, San Francisco, USA

\section{S.-C. Tham $(\bowtie)$}

Department of Radiology, Tan Tock Seng Hospital,

11 Jalan Tan Tock Seng,

Singapore 308433, Singapore

e-mail: Seng_Choe_Tham@ttsh.com.sg 


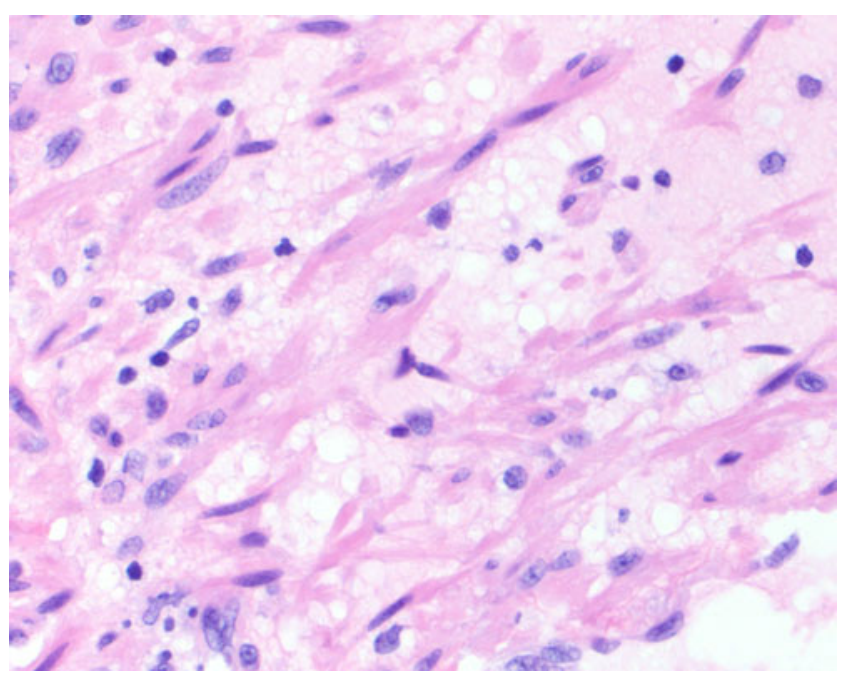

Fig. 3 At high power, the majority of tumor cells demonstrated fusiform pale eosinophilic cytoplasm and elongated, blunt-ended nuclei (original magnification, $\times 400$ ). These cells were strongly positive for the smooth muscle marker h-caldesmon by immunohistochemistry (not shown)

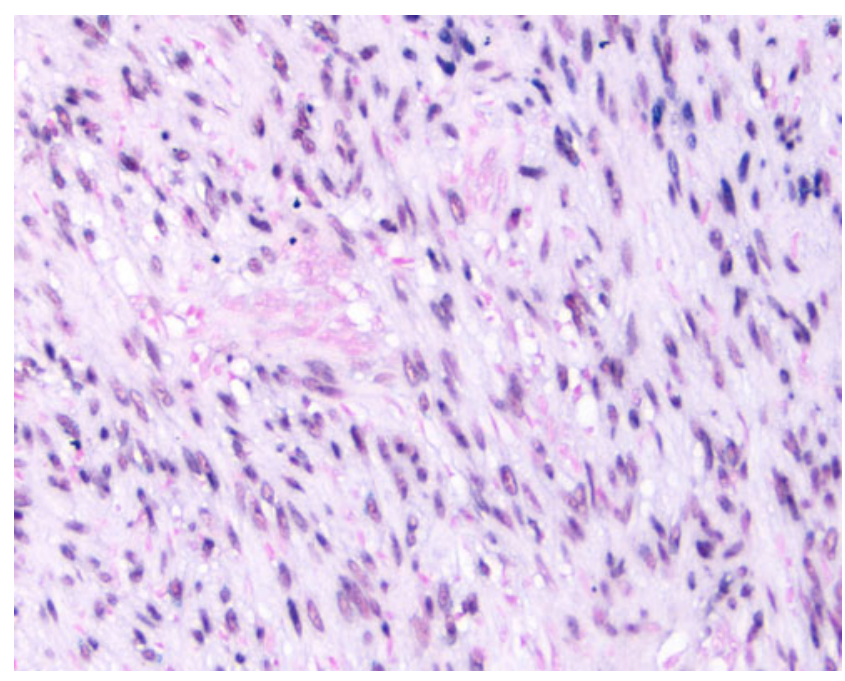

Fig. 4 In situ hybridization for the $L A N A$ gene showed expression in smooth muscle cells and lymphocytes (original magnification, $\times 200$ ) 